\title{
The effect of prolactin and estrogen cross-talk on prolidase- dependent signaling in MCF-7 cells
}

\author{
A. SURAZYNSKI ${ }^{1}$, W. MILTYK ${ }^{1}$, S. WOLCZYNSKI ${ }^{2}$, J. PALKA ${ }^{1, *}$ \\ ${ }^{1}$ Department of Medicinal Chemistry, Medical University of Bialystok, Kilińskiego 1, 15-089 Bialystok, Poland; ${ }^{2}$ Department of Gynaecological \\ Endocrinology, Medical University of Białystok, Skłodowskiej 24 A, 15-089 Białystok, Poland
}

*Correspondence: e-mail: pal@umb.edu.pl

Received October 22, 2012 / Accepted December 6, 2012

\begin{abstract}
Estrogen and prolactin play important role in mammary carcinogenesis. The present study was undertaken to evaluate the effect of prolactin and estrogen cross-talk on HIF-1 $\alpha$ level and expression of some HIF-1 $\alpha$ - dependent signaling proteins. Since up-regulation of prolidase activity inhibits HIF-1 a degradation, the enzyme was considered as an interface of estrogen/prolactin signaling. The experiments were performed on MCF-7 cells cultured with prolactin in the presence or absence of estradiol. It was found that in the presence of estradiol, prolactin inhibits prolidase activity and its down-stream signaling proteins: HIF-1a, mTOR, AKT and MAPK p-38, while in the absence of estradiol, an opposite effect was observed. These results suggest that prolactin/estrogen cross-talk exert beneficial effect on prolidase-dependent down regulation of HIF-1 $\alpha$. It suggests that dual action of prolactin and estrogen may be considered as a strategy in therapy of breast cancer.
\end{abstract}

Key words: prolactin, estrogen, HIF-1 $\alpha$, MCF-7, prolidase, cross-talk

The role of estrogen and their receptors in the promotion and development of breast cancer is well documented by epidemiological data and the therapeutical efficacy of antiestrogen therapy [1]. Similarly, it was shown that prolactin (PRL) also may play an important role in mammary carcinogenesis. PRL is a hormone synthesized as a $23-\mathrm{kDa}$ peptide by the anterior pituitary gland, however it can be produced also locally by the tumor. PRL receptor (PRL-R) is overexpressed in 70-95\% of primary breast tumors compared to normal adjacent tissue $[2,3,4,5]$ Prospective epidemiological studies have correlated circulating PRL levels with risk for estrogen receptor-alpha $(\mathrm{ER} \alpha)$-positive breast cancer in pre-and post-menopausal women [6]. However up to now the mechanism of prolactin action in breast cancer is not clear.

More direct evidence was obtained with estrogen receptor (ER) positive breast cancer cell lines in which estrogens were found to stimulate the proliferation of these cells both in culture [7] and in nude mice [8]. However, ER positive tumor cells are poorly metastatic compared to ER negative ones [9] and more responsive to antiestrogens [10]. It may suggest a regulatory role of estrogens in breast cancer cell metastasis.

The integrity of the extracellular matrix (ECM) is of critical importance for the maintenance of normal tissue. The interac- tion between cells and ECM proteins, e.g. collagen, can regulate cellular gene expression, differentiation, growth and plays an important role in tumorigenicity and invasiveness $[11,12]$.

Estrogens are well known stimulators of collagen biosynthesis and cell growth in several cell types [13-15]. Cell locomotion requires extensive degradation of ECM components, including collagens [16]. Although extracellular metalloproteinases initiate the breakdown of collagen, the final step of its degradation is mediated by prolidase.

Prolidase (E.C.3.4.13.9) is the enzyme that catalyzes the final step in ECM degradation by releasing proline or hydroxyproline from the carboxyl terminus of imidodipeptides [17]. Our previous study showed that prolidase participates not only in post-transcriptional regulation of collagen biosynthesis but is involved also in regulation at transcriptional level [18]. Several reports suggest that prolidase through regulation of expression of growth factors and transcription factors, e.g. vascular endothelial growth factor (VEGF), hypoxia inducible factor $1 \alpha$ (HIF-1 $\alpha$ ), transforming growth factor $\beta$ (TGF- $\beta$ ) [18-20] may be important in many physiologic and pathologic processes like: wound healing, inflammation and angiogenesis. The most representative study demonstrated the role of products of prolidase activity, proline or hydroxyproline in regulation 
of HIF-1 a degradation. Overexpression of prolidase resulted in increased HIF-1 a levels and elevated expression of HIF-1 a dependent gene products, VEGF and glucose transporter-1 (Glut-1). Mechanism for the accumulation of HIF-1 a was due to the inhibition of von Hippel-Lindau (VHL)-dependent degradation [18]. It seems that in specific conditions, like that of hypoxia, the metabolic system senses ECM degradation as a stress condition which requires neoangiogenesis. It may have importance in inflammation [21] and prolidase deficiency $[22,23]$.

Angiogenesis plays a key role in promoting tumorigenesis and metastasis. It is well established that prolactin has potent anti-angiogenic activity. The mechanism includes inhibition of potent angiogenic factor, VEGF [24]. On the other hand, crosstalk between PRL and estrogen is described. This phenomenon can occur at multiple levels. PRL increases ERa and ER $\beta$ transcription [25], and enhances estrogen receptor sensitivity and signaling, that affect tumor differentiation $[26,27]$. In MCF-7 cells, PRL and estrogen augment AP-1 activity through increased phosphorylation of p38, ERK1/2, c-Fos [28] and PI3K/AKT pathways [29,30]. Phosphorylation of multiple serine residues can enhance ER $\alpha$ transcriptional activity even in the absence of estrogen, which may be further augmented by phosphorylation of coactivators by the same kinases [31-33]. Conversely, estrogen also can alter PRL-induced signaling. Estrogen upregulates transcription of PRL in breast cancer cells $[34,35]$, enhancing the mammary PRL autocrine/paracrine loop.

The current study was therefore undertaken to characterize the effect of prolactin and estrogen cross-talk on prolidasedependent signaling in breast cancer (MCF-7) cell line.

\section{Materials and methods}

Materials. L-glycyl-L-proline, L-proline, and Dulbecco `s modified Eagle's medium with or without phenol red (DMEM) or controlled process serum replacement I, (CPSR1), sodium bicarbonate, penicillin, streptomycin, fetal bovine serum (FBS) used in cell culture, Dulbecco's phosphate buffered saline (DPBS), 5-bromo-4-chloro-3-indolyl phosphate/nitro blue tetrazolium liquid substrate reagent (BCIP/NBT), Prolactin was obtained from BioVision. Inc. Monoclonal (mouse) anti- phospho - MAPK (p-38, ERKs) antibody, Monoclonal (mouse) anti- phospho - AKT, anti-Rabbit IgG antibody, anti-Mouse IgG antibody, were purchased from Sigma Chemicals Co., USA, as were most other chemicals used. Monoclonal (mouse) anti- estrogen receptor a (ER $\alpha$ ), polyclonal (rabbit) anti - NF- $\kappa B$ antibody was obtained from Santa Cruz Biotechnology, Inc., USA, polyclonal (rabbit) anti - phospho mTOR was provided by Cell Signaling Technology, Inc USA, prolactin receptor (PRL-R) was purchased from Alexis Biochemicals CA, USA and monoclonal (mouse) anti- HIF-1a was obtained from BD Transduction Laboratories, CA, USA. Nitrocellulose membrane $(0.2 \mu \mathrm{m})$, sodium dodecylsulphate (SDS), polyacrylamide, molecular weight standards and Coomassie Briliant Blue R-250 were received from Bio-Rad Laboratories USA.

Cell cultures. The studies were performed on estrogendependent MCF-7 cells, expressing $\alpha$ and $\beta$ receptor. It is well known that estrogens stimulate collagen biosynthesis $[13,14,15]$. MCF-7 cells were maintained in DMEM without phenol red supplemented with $10 \%$ CPSR $1,50 \mathrm{U} / \mathrm{ml}$ penicillin, $50 \mu \mathrm{g} / \mathrm{ml}$ streptomycin at $37^{\circ} \mathrm{C}$ in a $5 \% \mathrm{CO}_{2}$ incubator. Cells were cultured in Costar flasks and sub-confluent cells were detached with $0.05 \%$ trypsin, $0.02 \%$ EDTA in calcium-free phosphate buffered saline, counted in hemocytometer and plated at $5 \times 10^{5}$ cells per well of 6-well plates (Nunc) in $2 \mathrm{ml}$ of growth medium. Cells reached about $80 \%$ of confluence at day 2 after plating and in most cases such cells were used for the assays.

Western blot analysis. Slab SDS/PAGE was used, according to the method of Laemmli [36]. After SDS-PAGE, the gels were allowed to equilibrate for $5 \mathrm{~min}$. in $25 \mathrm{mM}$ Tris, 0.2 M glycine in $20 \%(\mathrm{v} / \mathrm{v})$ methanol. The proteins were transfered to $0.2 \mu \mathrm{m}$ pore-sized nitrocellulose at $100 \mathrm{~mA}$ for 1 hour by using a LKB 2117 Multiphor II electrophoresis unit. The nitrocellulose was incubated with: monoclonal anti-MAPK antibody (p38 and ERK1/2), phosho-AKT, HIF-1a, ER $\alpha$, PRL-R, polyclonal phosho-mTOR, PRL at concentration 1:1,000 and polyclonal anti-NFkB antibody at concentration 1:500 in 5\% dried milk in Tris buffered saline with Tween 20 (TBS-T) $(20 \mathrm{mmol} / \mathrm{l}$ Tris- $\mathrm{HCl}$ buffer, $\mathrm{pH} 7.4$, containing 150 $\mathrm{mmol} / \mathrm{l} \mathrm{NaCl}$ and $0.05 \%$ Tween 20 ) for 1 hour. In order to analyze NF-kB, anti-Rabbit IgG (whole molecule) alkaline phosphatase conjugated was added at concentration 1:5,000 in TBS-T. In order to analyze MAP-kinases, AKT, HIF-1a, mTOR, ER $\alpha$, PRL-R second antibody-alkaline phosphatase conjugated, anti-Mouse IgG (whole molecule) was added at concentration 1:5,000 in TBS-T and incubated for $30 \mathrm{~min}$. slowly shaking. Then nitrocellulose was washed with TBS-T (5 $x 5 \mathrm{~min}$ ) and submitted to 5-bromo-4-chloro-3-indolyl phosphate/nitro blue tetrazolium liquid substrate reagent (BCIP/NBT).

Prolidase activity. The activity of prolidase was determined according to the method of Myara [17], which is based on colorimetric determination of proline using Chinard's reagent Cells were scraped off and centrifuged at $200 \mathrm{x}$ g for 15 min and the supernatant was discarded. The cell pellet was suspended in $1 \mathrm{ml}$ of $50 \mathrm{mM}$ HEPES, $\mathrm{pH} 7.8$, and sonicated for $3 \times 10$ seconds at $0^{\circ} \mathrm{C}$. Samples were then centrifuged $(12,000 \mathrm{x} \mathrm{g}, 30 \mathrm{~min})$ at $4^{\circ} \mathrm{C}$ and the supernatant was used for protein determination (Bradford method). Activation of prolidase requires incubation with $\mathrm{Mn}(\mathrm{II}): 100 \mu \mathrm{l}$ of cell extract supernatant was mixed with $100 \mu \mathrm{l}$ of $50 \mathrm{mM}$ HEPES, $\mathrm{pH}$ 7.8 containing $\mathrm{MnCl}_{2}$ at a final concentration of $1 \mathrm{mM}$ in the mixture. After incubation for 24 hours at $37^{\circ} \mathrm{C}$, the prolidase reaction was initiated by adding $100 \mu \mathrm{l}$ of the activated mixture to $100 \mu \mathrm{l}$ of $94 \mathrm{mM}$ glycyl-proline (Gly-Pro) for a final concentration of $47 \mathrm{mM}$. After additional incubation for 1 hour at $37^{\circ} \mathrm{C}$, the reaction was terminated with the addition 
of $1 \mathrm{ml}$ of $0.45 \mathrm{M}$ trichloroacetic acid. To parallel blank tubes, trichloroacetic acid was added at time "zero". Samples were centrifuged at 10,000 x g for $15 \mathrm{~min}$. The released proline was determined by adding $0.5 \mathrm{ml}$ of the trichloroacetic acid supernatant to $2 \mathrm{ml}$ of a 1:1 mixture of glacial acetic acid: Chinard's reagent $\left(25 \mathrm{~g}\right.$ of ninhydrin dissolved at $70^{\circ} \mathrm{C}$ in 600 $\mathrm{ml}$ of glacial acetic acid and $400 \mathrm{ml}$ of $6 \mathrm{M}$ orthophosphoric acid) and incubated for $10 \mathrm{~min}$ at $90^{\circ} \mathrm{C}$. The amount of proline released was determined colorimetrically by monitoring absorbance at $515 \mathrm{~nm}$ and calculated using proline standards. Enzyme activity was reported in nanomoles of proline released per minute per milligram of protein.

Statistical analysis. For prolidase activity analysis, the mean values for 3 assays done in duplicates \pm standard deviations (S.D.) were calculated. The results were analyzed by ANOVA method, accepting $\mathrm{P}<0.05$, as significant.

\section{Results}

It has been documented that estrogens up-regulate prolidase activity $[15,37]$. In cultured cells, phenol red contained in medium mimics activity of estrogens [38]. We found that in MCF-7 cell incubated without phenol red in medium, expression of estrogen receptor a (ER $\alpha$ ) was markedly reduced compared to cells cultured in medium with phenol red (Fig.1A). An addition of $1 \mathrm{nM}$ estradiol to cells cultured in phenol red slightly up-regulated ER a expression while had no effect on the receptor expression in cells cultured without phenol red. On the other hand the presence or absence of estradiol in medium had no effect on expression of prolactin receptor (Fig. 1B) However, prolactin up-regulated prolactin receptor (PRL-R) expression. The stimulation of PRL-R expression by PRL was more effective in cells cultured in medium without estradiol than in cells cultured in medium with estradiol (Fig. 1B).

Therefore, in the further experiments we used breast cancer MCF-7 cells cultured in medium without phenol red, containing $10 \%$ CPSR1 with or without $1 \mathrm{nM}$ estradiol. In order to evaluate the effect of PRL on estrogen - dependent prolidase activity we used different concentration of PRL. It was found that PRL, in the presence of estradiol, inhibits prolidase activity in MCF-7 cells in a dose dependent manner (Fig. 2). However, in the absence of estradiol, PRL was found to stimulate activity of this enzyme. As can be seen from Fig.2, $1 \mathrm{nM}$ estradiol is a potent stimulator of prolidase activity in MCF-7 cells. About $60 \%$ increase in prolidase activity was observed in the cells treated for 24 hours with medium containing $1 \mathrm{nM}$ estradiol, compared to control without estradiol. An addition of PRL at 1 and $25 \mu \mathrm{M}$ concentrations to the estradiol containing medium, inhibited the enzyme activity by about 20 and $30 \%$ respectively. An opposite effect was observed in medium without estrogen. In this case PRL induced increase in prolidase activity in a dose dependent manner. At 1 and $25 \mu \mathrm{M}$ of PRL the activity of prolidase was close to values found in control - estradiol treated cells.

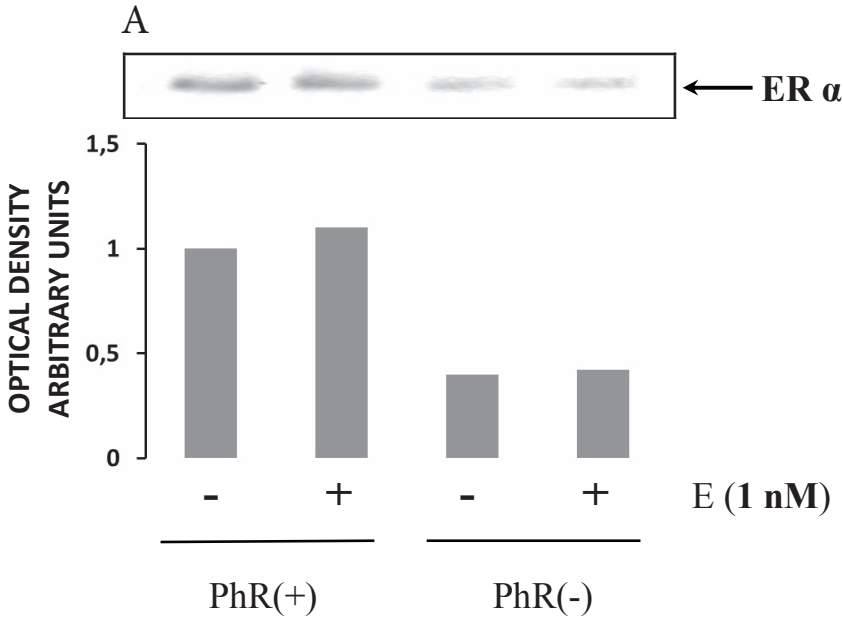

B

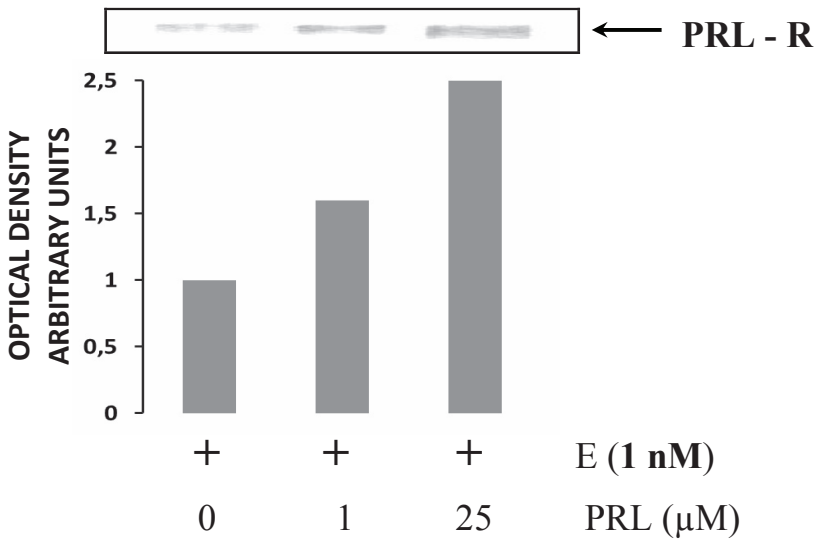

C

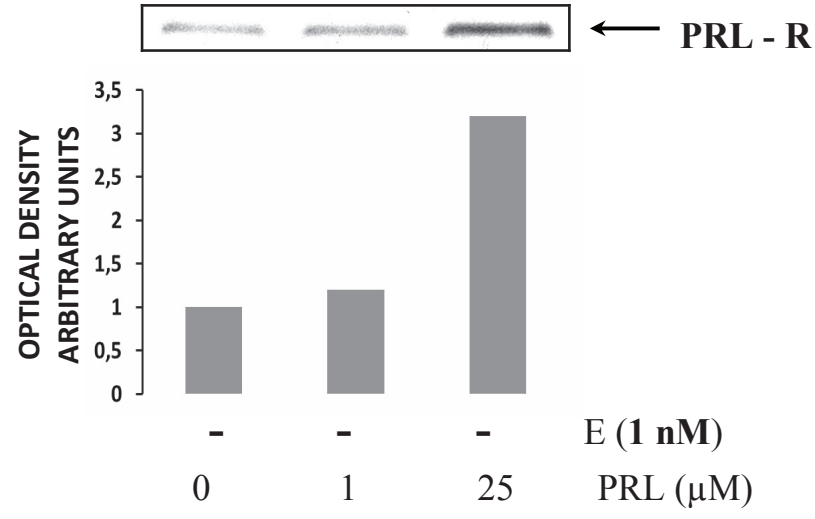

Figure 1. A. Western blot for estrogen (ER) in MCF-7 cells cultured in the absence $(-)$ or presence $(+)$ of $1 \mathrm{nM}$ estrogen $(\mathrm{E})$ in DMEM with $(\mathrm{PhR}+)$ or without (PhR-) phenol red and 10\% CPSR1 for 24 hours.

B. Western blot for prolactin receptor (PRL-R) in MCF-7 cells cultured in the absence (-) or presence (+) of $1 \mathrm{nM}$ estrogen (E) in DMEM without phenol red and $10 \%$ CPSR 1 and submitted for 24 hours to different concentrations of Prolactin (PRL). Samples used for electrophoresis consisted $20 \mu \mathrm{g}$ of protein from 6 pooled cell extracts $(n=6)$. The band staining was quantified by densitometry. 


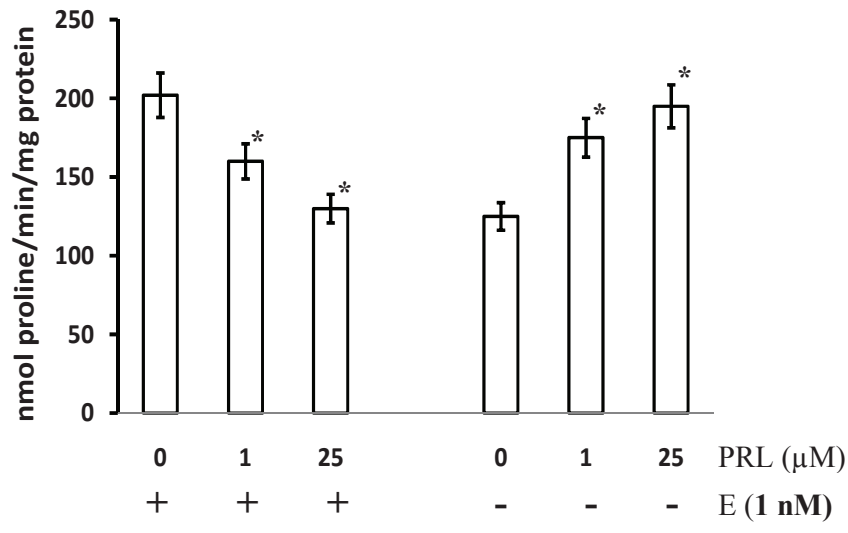

Figure 2. Effect of different concentration of Prolactin (PRL) on prolidase activity in MCF-7 cells, cultured in the absence (-) or presence (+) of $1 \mathrm{nM}$ estrogen (E) in DMEM without phenol red with $10 \%$ CPSR1. The data represent mean values + S.D. of 3 determinations done in duplicates. Statistical analysis of difference between control and treated cells showed significance at ${ }^{*} \mathrm{P}<0.05$.

In order to establish whether MAP-kinases, ERK1/2 and p38 (known to regulate prolidase activity) and AKT are involved in regulation of some transcription factors, as HIF- $1 \alpha, \mathrm{NF}-\kappa \mathrm{B}$, mTOR, we decided to evaluate the expression of these factors in studied cells in the same conditions as those described for prolidase activity experiment. We have found that in the presence of estrogen, PRL inhibited expression of HIF-1 a (Fig. 3A) and phosphorylation of mTOR (Fig. 3C), but induced expression of $\mathrm{NF} \kappa \mathrm{B}$ in dose dependent manner (Fig.4A). An opposite effect was observed in the absence of estrogen in the medium. In this case PRL drastically increased the expression of HIF-1 a (Fig. 3B) and phosphorylation of mTOR (Fig. 3D), while it decreased the expression of $\mathrm{NF \kappa B}$ in a dose dependent manner (Fig 4B).

In order to establish whether kinases, which regulate prolidase functions, MAP-kinases $\left(\mathrm{ERK}_{1} / \mathrm{ERK}_{2}\right.$ and $\left.\mathrm{p}-38\right)$ and AKT are involved in PRL dependent functions, the expression of these proteins was analyzed by Western blot. As can be seen on Fig. 5 in the presence of estrogen in the medium, PRL induced inhibition of phosphorylation of AKT (Fig. 5A) and phosphorylation of p-38 MAP kinase (Fig. 5C). In the absence of estrogen in the medium an opposite effect was observed. PRL stimulated phosphorylation of AKT (Fig. 5B) and phosphorylation of p38 (Fig. 5D), while it had no effect on the phosphorylation of $\mathrm{ERK}_{1} / \mathrm{ERK}_{2}$ either in the presence (Fig. 5E) or absence (Fig.5F) of estradiol.
A

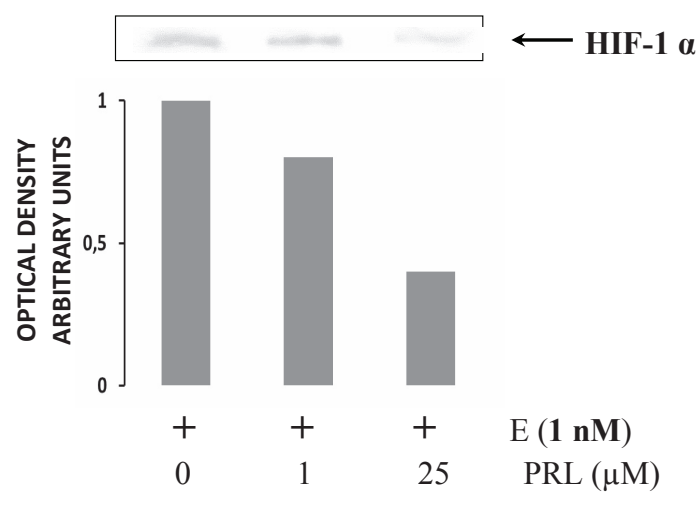

$\mathrm{C}$

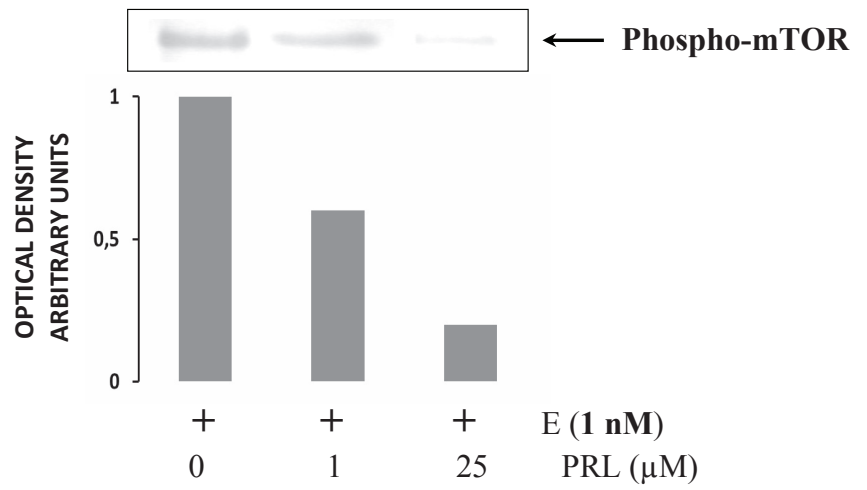

$\mathrm{B}$

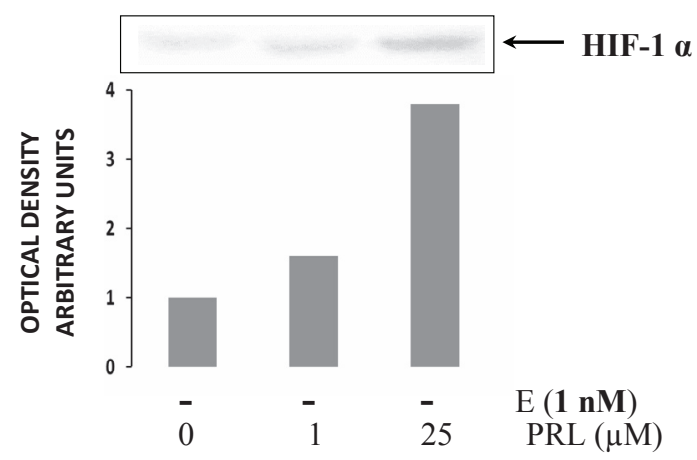

$\mathrm{D}$

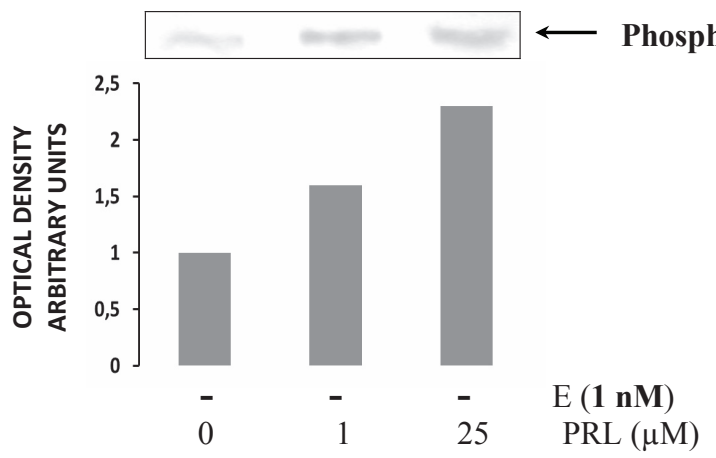

Figure 3. Western blot analysis for HIF-1 a (A, B), Phospho-mTOR (C, D) in MCF-7 cells cultured in the absence (-) or presence (+) of $1 \mathrm{nM}$ estrogen in DMEM without phenol red with $10 \%$ CPSR 1 and submitted for 24 hours to different concentrations of Prolactin (PRL). Samples used for electrophoresis consisted of $20 \mu \mathrm{g}$ of protein from 6 pooled cell extracts $(n=6)$. The band staining was quantified by densitometry. 
A

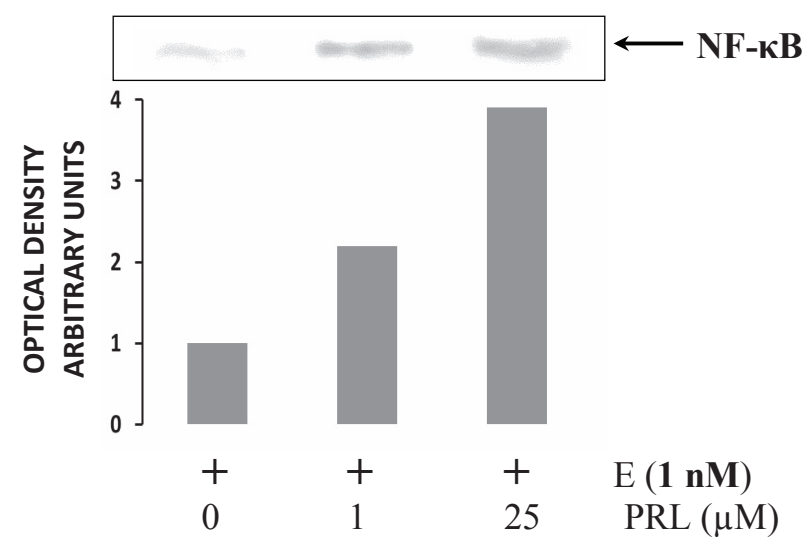

B

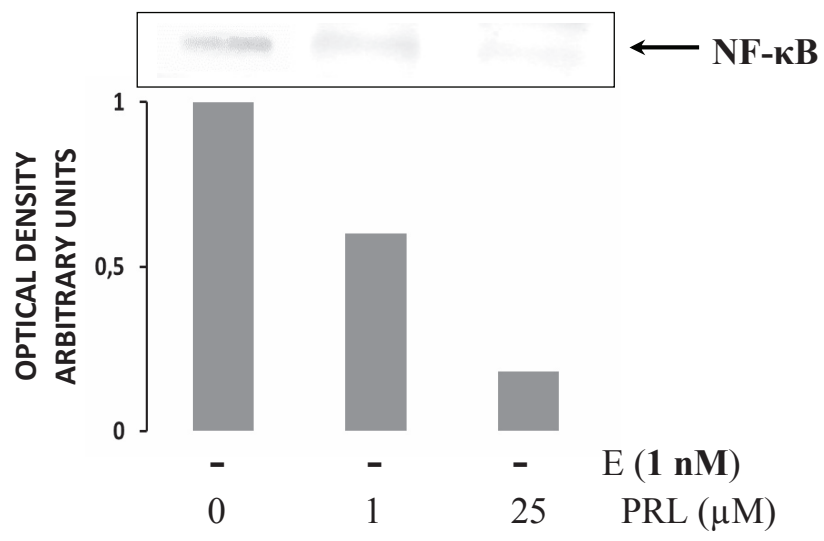

Figure 4. Western blot analysis for NF- $\mathrm{B}$ in MCF-7 cells cultured in the presence (A) or absence (B) of $1 \mathrm{nM}$ estrogen (E) in DMEM without phenol red with $10 \%$ CPSR 1 and submitted for 24 hours to different concentrations of Prolactin (PRL). Samples used for electrophoresis consisted of $20 \mu \mathrm{g}$ of protein from 6 pooled cell extracts $(n=6)$. The band staining was quantified by densitometry.

\section{Discussion}

Estrogens are known to stimulate the growth of normal and transformed cells, including epithelial cells [39]. The mechanism of their action involves interaction with estrogen receptor that after binding of ligand is targeted to the nucleus as a transcription factor [40]. Several studies documented increased risk of cancer in women with elevated circulating levels of estrogens [41-43]. However, activation of estrogen receptor is regulated not only by its ligands but also by number of factors, including kinases, phosphatases and growth factors [44]. For instance, in endometrial cancer cells, p38 mitogen-activated protein kinase (MAPK) signaling phosphorylates estrogen receptor $\alpha$, promoting its nuclear localization [45].

Despite the fact that estrogens play an important role in the promotion and development of female epithelial-derived cancer [46], it has been postulated that estrogen receptor (ER) positive cancer cells are poorly metastatic compared to ER negative ones [9]. The mechanism of the regulatory role of estrogens in cancer cell growth and metastasis however is not understood. Although in this report we do not study growth and metastasis of MCF-7 cells, the approach to the understanding the effect of estrogens on the processes is focused on the role of PRL on prolidase-dependent signaling. Although it has been postulated that PRL increases breast cancer risk, some data suggest that it may be the key, two-sided, in human breast tissue homeostasis [47]. It seems that the action of PRL depends on the status of estrogen receptor activation. In this report we have shown such a mechanism in respect to regulation of prolidase activity. In the presence of estradiol, prolactin inhibited prolidase activity and its down-stream signaling proteins: HIF-1 $\alpha$, mTOR, AKT and MAPK p-38, while in the absence of estradiol, an opposite effect was found. Therefore depending on the presence or absence of estrogen receptor activation, prolactin may exert differential effect on prolidase activity.

It seems that in the context of breast cancer, the most important is contribution of prolidase to regulation of HIF-1a. The stability and activity of HIF-1 $\alpha$ are regulated by various post-translational modifications, hydroxylation, acetylation, and phosphorylation. Under normoxia, the HIF-1 $\alpha$ subunit is rapidly degraded via the von Hippel - Lindau tumor suppressor gene product (pVHL)- mediated ubiquitin-proteasome pathway. The association of pVHL and HIF-1 $\alpha$ under normoxic conditions is triggered by the hydroxylation of prolines and the acetylation of lysine within a polypeptide segment known as the oxygen-dependent degradation (ODD) domain. On the contrary, in the hypoxia condition, HIF-1a subunit becomes stable and interacts with coactivators such as p300/ CBP to modulate its transcriptional activity. Overexpression of prolidase resulted in increased nuclear HIF-1a levels and elevated expression of HIF-1-dependent gene products, vascular endothelial growth factor (VEGF) and glucose transporter-1 (Glut-1). The activation of HIF-1-dependent transcription was shown by prolidase-dependent activation of HRE-luciferase expression. We used an oxygen-dependent degradation domain (ODD)-luciferase reporter construct as a surrogate for HIF-1a in an in situ prolyl-hydroxylase assay. Since this reporter is degraded by VHL-dependent mechanisms, increased levels of HIF-1a with prolidase expression were due to decreased hydroxylation. Additionally, the differential expression of prolidase in two breast cancer cell lines MCF-7 and MDA MB - 231 showed prolidasedependent differences in HIF-1a levels [18]. These findings show that metabolism of imidodipeptides by prolidase plays a previously unrecognized role in angiogenic signaling, cell proliferation/survival, and glucose metabolism.

Another consequence of the cross-talk between estrogen and PRL was found at the level of NF-kB (known inhibitor 
A

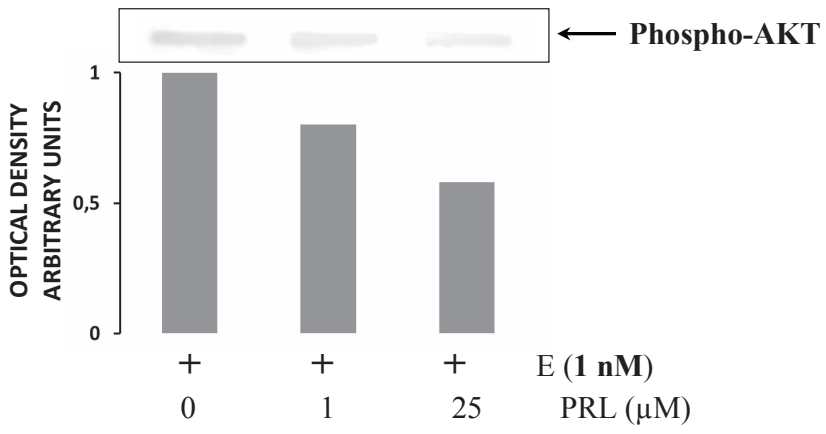

$\mathrm{C}$

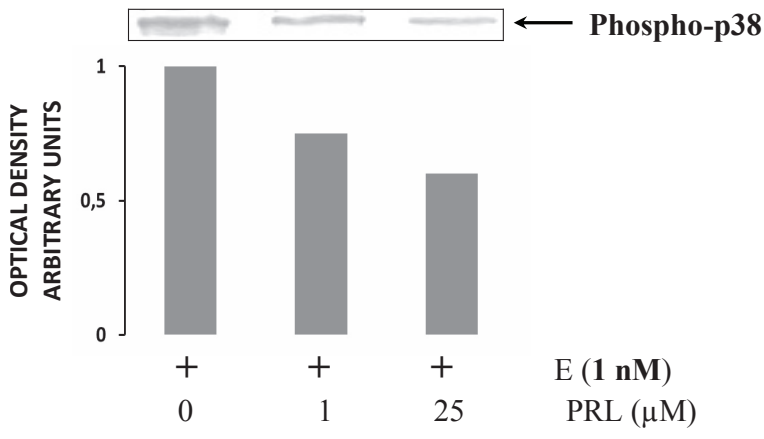

E

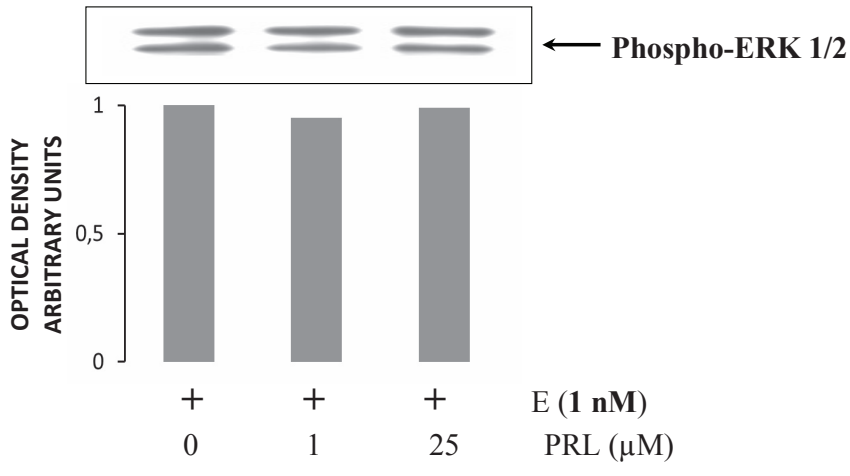

B

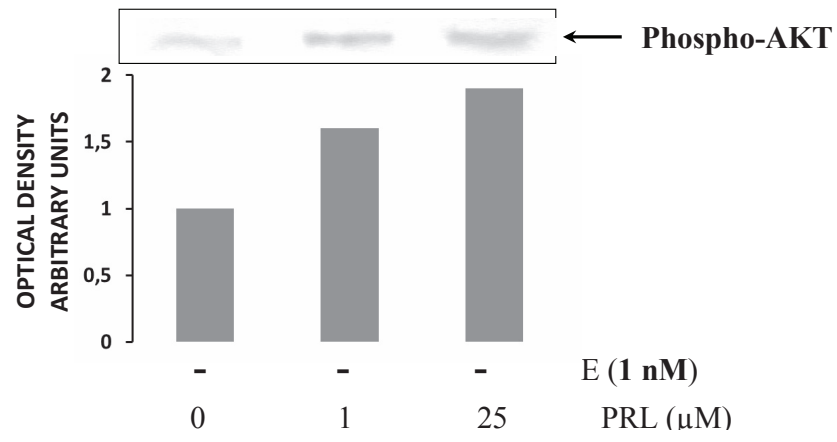

$\mathrm{D}$

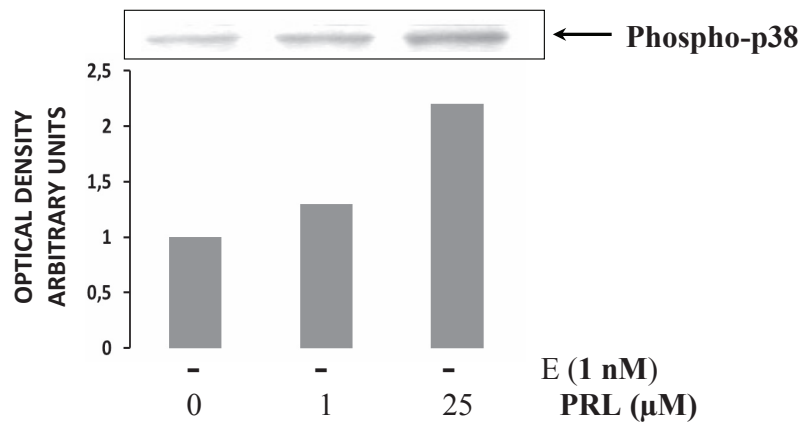

F
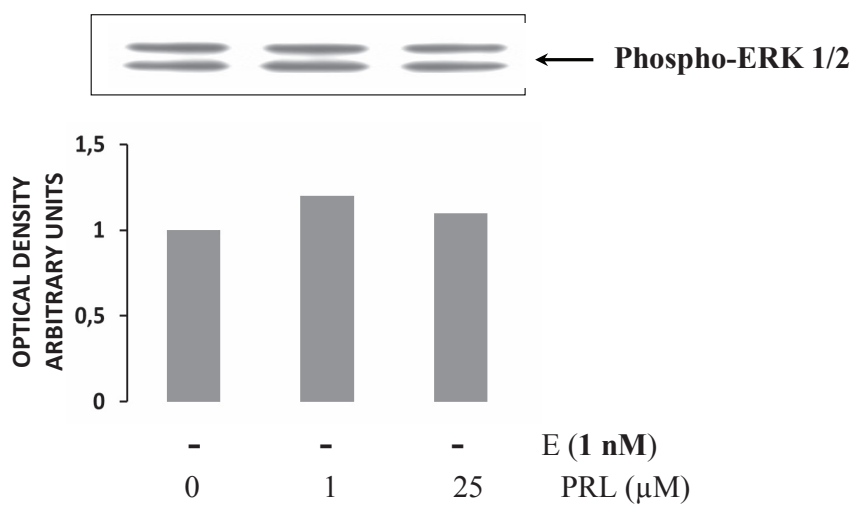

Figure 5. Western blot analysis for Phospho-AKT (A, B), Phospho-p38 (C, D) Phospho-ERK1/2 (E, F) in MCF-7 cells cultured in the absence (-) or presence $(+)$ of $1 \mathrm{nM}$ estrogen (E) in DMEM without phenol red with 10\% CPSR1 and submitted for 24 hours to different concentrations of Prolactin (PRL). Samples used for electrophoresis consisted of $20 \mu \mathrm{g}$ of protein from 6 pooled cell extracts $(n=6)$. The band staining was quantified by densitometry.

of collagen gene expression) and MAPK signaling. In our study PRL in the presence of estrogen was found to stimulate expression of NF-kB and inhibit phosphorylation of p-38 but not ERK1/ERK2, while in the absence of estrogen an opposite effect was found. Both stimulation of NF-kB and inhibition of p 38 MAPK contribute to down regulation of collagen production that is linked to prolidase activity. NF-kB is known to be involved in inhibition of collagen gene transcription through binding to both $\alpha 1$ and $\alpha 2$ collagen promoter $[48,49,50]$. NF$\kappa \mathrm{B}$ as transcription factor may regulate also apoptosis, cell proliferation, cell growth arrest, as well as angiogenesis via stimulation of vascular endothelial growth factor expression [51]. On the other hand MAPK p-38 is known as an signaling inductor of collagen production acting through up-regulation 
of TGF $\beta 1$ gene expression [52]. Inhibition of MAPK p-38 phosphorylation by PRL-estrogen cross-talk may also affect phosphorylation of estrogen receptor and its translocation to the nucleus [53].

All those activities of PRL-estrogen cross-talk may have also another consequences, as inhibition of collagen biosynthesis protecting against tissue fibrosis accompanying aging, oxidative stress, high blood glucose level and others [54,55]. Decrease in collagen biosynthesis may also eliminate collagen as a ligand for integrins, that play important role in signaling in epithelial cancers, leading to cell proliferation. Interestingly all those activities requires participation of estrogen. What is the mechanism for the cross - talk between PRL and estrogen receptor needs to be resolved. Nevertheless, the data document for the first time the inhibitory effect of PRL-estrogen cross-talk on prolidase activity regulation and its down-stream signaling. It suggests that dual action of PRL and estrogen may be considered as a strategy in therapy of breast cancer.

\section{Conclusions}

These results suggest that prolactin requires estrogen to exert beneficial effect on prolidase-dependent down regulation of HIF-1 $a$. It suggests that dual action of prolactin and estrogen may be considered as a strategy in therapy of breast cancer.

Acknowledgments: This work was supported by Grants No. 3-14542 F and 113-04947 L from the Committee for Scientific Research.

\section{References}

[1] JORDAN VC. The strategic use of antiestrogens to control the development and growth of breast cancer. Cancer 1992; 15: 977-982.

[2] ORMANDY CJ, HALL RE, MANNING DL, ROBERTSON JF, BLAMEY RW et al. Coexpression and cross-regulation of the prolactin receptor and sex steroid hormone receptors in breast cancer. J Clin Endocrinol Metab 1997; 82: 3692-3699. http://dx.doi.org/10.1210/jc.82.11.3692

[3] REYNOLDS C, MONTONE KT, POWELL CM, TOMASZEWSKI JE, CLEVENGER CV. Expression of prolactin and its receptor in human breast carcinoma. Endocrinology 1997; 138: 5555-5560. http://dx.doi.org/10.1210/en.138.12.5555

[4] TOURAINE P, MARTINI JF, ZAFRANI B, DURAND JC, LABAILLE $\mathrm{F}$ et al. Increased expression of prolactin receptor gene assessed by quantitative polymerase chain reaction in human breast tumors versus normal breast tissues. J Clin Endocrinol Metab 1998; 83: 667-674. http://dx.doi. org/10.1210/jc.83.2.667

[5] GILL S, PESTON D, VONDERHAAR BK, SHOUSHA S. Expression of prolactin receptors in normal, benign, and malignant breast tissue: an immunohistological study. J Clin Pathol 2001; 54: 956-960. http://dx.doi.org/10.1136/ jcp.54.12.956
[6] TWOROGER SS, HANKINSON SE. Prolactin and breast cancer etiology: an epidemiologic perspective. J Mammary Gland Biol Neoplasia 2008; 13: 41-53. http://dx.doi. org/10.1007/s10911-008-9063-y

[7] DICKSON RB, LIPPMAN ME. Control of human breast cancer by estrogen, growth factors, and oncogenes. Cancer Treat Res 1988; 40: 119-165. http://dx.doi.org/10.1007/9781-4613-1733-3 6

[8] OSBORNE CK, HOBBS K, CLARK GM. Effect of estrogens and antiestrogens on growth of human breast cancer cells in athymic nude mice. Cancer Res 1985; 45: 584-590.

[9] PRICE JE, POLYZOS A, ZHANG RD, DANIEL LM. Tumorigenicity and metastasis of human breast carcinoma cell lines in nude mice. Cancer Res 1990; 50: 717-721.

[10] LERNER LJ, JORDAN VC. Development of antiestrogens and their use in breast cancer: eighth Cain memorial award lecture. Cancer Res 1990; 50: 4177-4189.

[11] CAREY DJ. Control of growth and differentiation of vascular cells by extracellular matrix. Annu Rev Physiol 1991; 53: 161177. http://dx.doi.org/10.1146/annurev.ph.53.030191.001113

[12] Ruoslahti E. Control of cell motility and tumor invasion by extracellular matrix interaction. Br J Cancer 1992; 66: 239-242. http://dx.doi.org/10.1038/bjc.1992.250

[13] BALDEKAS JC, GERSTENFELD L, SONENSTEIN GE, FRANZBLAU C. Cell density and estradiol molulation of procollagen type III in cultured calf smooth muscle cells. J Cell Biol 1982; 257: 12262-12265.

[14] SCHMID MEC, FROESCH ER. Enhanced osteoblast proliferation and collagen gene expression by estradiol. Proc Natl Acad Sci U S A 1988; 85: 2307-2310. http://dx.doi. org/10.1073/pnas.85.7.2307

[15] SURAZYNSKI A, JARZABEK K, HACZYNSKI J, LAUDANSKI P, PALKA J et al. Differential effects of estradiol and raloxifene on collagen biosynthesis in cultured human skin fibroblasts. Int J Mol Med 2003; 12: 803-809.

[16] LIOTTA LA. Tumor invasion and metastases - role of the extracellular matrix. Cancer Res 1986; 46: 1-7.

[17] MYARA I, CHARPENTIER C, LEMONNIER A. Optimal conditions for prolidase assay by proline colorimetric determination: application to iminodipeptiduria. Clin Chim Acta 1982; 125:193-205. http://dx.doi.org/10.1016/00098981(82)90196-6

[18] SURAZYNSKI A, DONALD SP, COOPER SK, WHITESIDE MA, SALNIKOW et al. Extracellular matrix and HIF-1 signaling: the role of prolidase. Int J Cancer 2008; 122: 1435-1440. http://dx.doi.org/10.1002/ijc.23263

[19] SURAZYNSKI A, MILTYK W, PALKA J, PHANG JM. Prolidase-dependent regulation of collagen biosynthesis. Amino Acids 2008; 35: 731-738. http://dx.doi.org/10.1007/s00726008-0051-8

[20] SURAZYNSKI A, MILTYK W, PROKOP I, PALKA J. Prolidase-dependent regulation of TGF $\beta$ and TGF $\beta$ receptor expressions in human skin fibroblasts. Eur J Pharmacol 2010; 649: 115-119. http://dx.doi.org/10.1016/ j.ejphar.2010.09.034

[21] SURAZYNSKI A, LIU Y, MILTYK W, PHANG JM. Nitric oxide regulates prolidase activity by serine/threonine 
phosphorylation. J Cell Biochem 2005; 96: 1086-1094. http:// dx.doi.org/10.1002/jcb.20631

[22] ARATA J, TADA J, YAMADA T, OONO T, YASUTOMI H et al Angiopathic pathogenesis of clinical manifestations in prolidase deficiency. Arch Dermatol 1991; 127: 124-125. http://dx.doi.org/10.1001/archderm.1991.0168001013602 $\underline{8}$

[23] SEKIYA M, OHNISHI Y, KIMURA K, An autopsy case of prolidase deficiency. Virchows Arch 1985; 496: 125-131.

[24] DE LA TORRE NG, TURNER HE, WASS JA. Angiogenesis in prolactinomas: regulation and relationship with tumour behavior. Pituitary 2005; 8: 17-23. http://dx.doi.org/10.1007/ s11102-005-5081-6

[25] FRASOR J. GIBORI G. Prolactin regulation of estrogen receptor expression. Trends Endocrinol Metab 2003; 3: 118-123 http://dx.doi.org/10.1016/S1043-2760(03)00030-4

[26] WEBB P, LOPEZ GN, GREENE GL, BAXTER JD, KUSHNER PJ. The limits of the cellular capacity to mediate an estrogen response. Mol Endocrin 1992; 6: 157-167. http://dx.doi. org/10.1210/me.6.2.157

[27] SHARMA D, SAXENA NK, DAVIDSON NE, VERTINO PM. Restoration of tamoxifen sensitivity in estrogen receptor-negative breast cancer cells: tamoxifen-bound reactivated ER recruits distinctive corepressor complexes. Cancer Res 2006; 66: 6370-6378. http://dx.doi.org/10.1158/0008-5472. CAN-06-0402

[28] GUTZMAN JH, NIKOLAISE, RUGOWSKI DE, WATTERS JJ, SCHULER LA. Prolactin and estrogen enhance the activity of activating protein 1 in breast cancer cells: role of extracellularly regulated kinase 1/2-mediated signals to c-fos. Mol Endocrin 2005; 19: 1765-1778. http://dx.doi.org/10.1210/me.2004$\underline{0339}$

[29] GLAROS S, ATANASKOVA N, ZHAO C, SKAFAR DF, REDDY KB. Activation function-1 domain of estrogen receptor regulates the agonistic and antagonistic actions of tamoxifen. Mol Endocrin 2006; 20: 996-1008. http://dx.doi. org/10.1210/me.2005-0285

[30] ARENDT LM, SCHULER LA. Prolactin drives ERa-dependent ductal expansion and synergizes with transforming growth factor-alpha to induce mammary tumors in males. Am J Pathol 2008; 172: 194-202. http://dx.doi.org/10.2353/ ajpath.2008.070597

[31] LIKHITE VS, STOSSI F, KIM K, KATZENELLENBOGEN BS, KATZENELLENBOGEN JA. Kinase-specific phosphorylation of the estrogen receptor changes receptor interactions with ligand, DNA, and coregulators associated with alterations in estrogen and tamoxifen activity. Mol Endocrin 2006; 20: 3120-3132. http://dx.doi.org/10.1210/me.2006-0068

[32] WEIGEL NL, MOORE NL. Steroid receptor phosphorylation: a key modulator of multiple receptor functions. Mol Endocrin 2007; 21: 2311-2319. http://dx.doi.org/10.1210/me.2007$\underline{0101}$

[33] GONZALEZ L, ZAMBRANO A, LAZARO-TRUEBA I, LOPEZ E, GONZALEZ JJ et al. Activation of the unliganded estrogen receptor by prolactin in breast cancer cells. Oncogene 2009; 28: 1298-1308. http://dx.doi.org/10.1038/ onc. 2008.473
[34] DONG J, TSAI-MORRIS CH, DUFAU ML. A novel estradiol/ ERa-dependent transcriptional mechanism controls expression of the human prolactin receptor. J Biol Chem 2006; 281: 18825-18836. http://dx.doi.org/10.1074/jbc.M512826200

[35] DUAN R, GINSBURG E, VONDERHAAR BK. Estrogen stimulates transcription from the human prolactin distal promoter through AP-1 and estrogen responsive elements in T47D human breast cancer cells. Mol Cel Endocrin 2008; 281: 9-18. http://dx.doi.org/10.1016/j.mce.2007.10.004

[36] LAEMMLI UK. Cleavage of structural proteins during the assembly of the head of bacteriophage T4. Nature 1970; 227: 680-685. http://dx.doi.org/10.1038/227680a0

[37] MILTYK W, ANCHIM T, WOLCZYNSKI S, PALKA J. Estrogen-dependent regulation of prolidase activity in breast cancer MCF-7 cells. Gynecol Endocrinol 1999; 13: 166-174. http://dx.doi.org/10.3109/09513599909167551

[38] DEVLEESCHOUWER N, BODY JJ, LEGROS N, MUQUARDT C, DONNAY I et al. Growth factor-like activity of phenol red preparations in the MCF-7 breast cancer cell line. Anticancer Res 1992; 12: 789-794.

[39] KEY TJ, PIKE MC. The dose-effect relationship between „unopposed“ oestrogens and endometrial mitotic rate: its central role in explaining and predicting endometrial cancer risk. Br J Cancer 1988; 57: 205-212. http://dx.doi.org/10.1038/bjc.1988.44

[40] TSAI MJ, O`MALLEY BW. Molecular mechanism of action of steroid/thyroid receptor superfamily members. Annu Rev Biochem 1994; 63: 451-486. http://dx.doi.org/10.1146/annurev.bi.63.070194.002315

[41] AUSTIN H, AUSTIN JM JR, PARTRIDGE EE, HATCH KD, SHINGLETON HM. Endometrial cancer, obesity, and body fat distribution. Cancer Res 1991; 51: 568-572.

[42] POTISCHMAN N, HOOVER RN, BRINTON LA, SIITERI P, DORGAN JF et al. Case-control study of endogenous steroid hormones and endometrial cancer. J Natl Cancer Inst 1996; 88: 1127-1135. http://dx.doi.org/10.1093/jnci/88.16.1127

[43] ZELENIUCH-JACQUOTTE A, AKHMEDKHANOV A, KATO I. Postmenopausal endogenous oestrogens and risk of endometrial cancer: results of a prospective study. Br J Cancer 2001; 84: 975-981. http://dx.doi.org/10.1054/ bjoc.2001.1704

[44] SMITH CL. Cross-talk between peptide growth factor and estrogen signaling pathways. Biol Reprod 1998; 58: 627-632. http://dx.doi.org/10.1095/biolreprod58.3.627

[45] LEE H, BAI W. Regulation of estrogen receptor nuclear export by ligand-induced and p-38-mediated receptor phosphorylation. Mol Cel Biol 2002; 22: 5835-5845. http://dx.doi. org/10.1128/MCB.22.16.5835-5845.2002

[46] JORDAN VC. Overview from the International Conference on Long-Term Tamoxifen Therapy for Breast Cancer. J Natl Cancer Inst 1992; 84: 231-234. http://dx.doi.org/10.1093/ jnci/84.4.231

[47] GOODMAN G, BERCOVICH D. Prolactin does not cause breast cancer and mayprevent it or be therapeutic in some conditions. Med Hypotheses 2008; 70: 244-251. http://dx.doi. org/10.1016/j.mehy.2007.05.027

[48] KOUBA DJ, CHUNG KY, NISHIYAMA T, VINDEVOGHEL L, KON A et al. Nuclear factor-kappa B mediates TNF-alpha inhibi- 
tory effect on alpha 2[I] collagen [COL1A2] gene transcription in human dermal fibroblasts. J Immunol 1999; 162: 4226-4234.

[49] MILTYK W, KARNA E, PALKA JA. Prolidase-independent mechanism of camptothecin-induced inhibition of collagen biosynthesis in cultured human skin fibroblasts. J Biochem 2007; 141: 287-292. http://dx.doi.org/10.1093/ $\mathrm{jb} / \mathrm{mvm} 022$

[50] RIPPE RA, SCHRUM LW, STEFANOVIC B, SOLIS-HERRUZO JA, BRENNER DA. NF-kappaB inhibits expression of the alpha1[I] collagen gene. DNA Cell Biol 1999; 18: 751-761. http://dx.doi.org/10.1089/104454999314890

[51] KUMAR A, TAKADA Y, BORIEK AM, AGGARWAL BB. Nuclear factor- B: its role in health and disease. J Mol Med 2004; 82: 434-448. http://dx.doi.org/10.1007/s00109-004$\underline{0555-y}$
[52] CASTELLO L, FROIO T, CAVALLINI G, BIASI F, SAPINO A et al. Calorie restriction protects against age-related rat aorta sclerosis. FASEB J 2005; 19: 1863-1865.

[53] LEE H, BAI W. Regulation of estrogen receptor nuclear export by ligand-induced and p-38-mediated receptor phosphorylation. Mol Cel Biol 2002; 22: 5835-5845. http://dx.doi. org/10.1128/MCB.22.16.5835-5845.2002

[54] WANG T, XU J, YU X, YANG R, CHAO HAN Z. Peroxisome proliferator-activated receptor- $\gamma$ in malignant diseases. Crit Rev Oncol Hematol 2006; 58: 1-14. http://dx.doi.org/10.1016/ j.critrevonc.2005.08.011

[55] HOUSEKNECHT KL, COLE BM, STEELE PJ. Peroxisome proliferator-activated receptor- gamma [PPAR-gamma] and its ligands: a review. Domest Anim Endocrinol 2002; 22: 1-23. http://dx.doi.org/10.1016/S0739-7240(01)00117-5 